\title{
Glycine Transport Inhibitors for the Treatment of Schizophrenia
}

\author{
Kenji Hashimoto* \\ From the Division of Clinical Neuroscience, Chiba University Center for Forensic, Mental Health, 1-8-1 Inohana, \\ Chiba 260-8670, Japan
}

\begin{abstract}
Multiple lines of evidence indicate that hypofunction of glutamatergic neurotransmission via $N$-methyl-Daspartate (NMDA) receptors might be implicated in the pathophysiology of schizophrenia, suggesting that increasing NMDA receptor function via pharmacological manipulation could provide a new strategy for the management of schizophrenia. Currently, the glycine modulatory sites on NMDA receptors present the most attractive therapeutic targets for the treatment of schizophrenia. One means of enhancing NMDA receptor neurotransmission is to increase the availability of the obligatory co-agonist glycine at modulatory sites on the NMDA receptors through the inhibition of glycine transporter-1 (GlyT-1) on glial cells. Clinical studies have demonstrated that the GlyT-1 inhibitor sarcosine ( $N$ methyl glycine) shows antipsychotic activity in patients with schizophrenia. Accordingly, a number of pharmaceutical companies have developed novel and selective GlyT-1 inhibitors for the treatment of schizophrenia. This paper provides an overview of the various GlyT-1 inhibitors and their therapeutic potential.
\end{abstract}

Keywords: Schizophrenia; NMDA receptor; Glutamate; Glycine; Transporter; Glia.

\section{INTRODUCTION}

A growing body of evidence suggests that the $N$-methylD-aspartate (NMDA) receptors (Fig. 1) play a role in the pathophysiology of schizophrenia [1-12]. Subanesthetic doses of the non-competitive NMDA receptor antagonist phencyclidine (PCP; Fig. 2) have been shown to produce a wide range of transient schizophrenia-like symptoms, including estrangement, loss of body boundaries, formal thought disorder, hallucinations, and psychosis $[1,13,14]$. In addition, PCP is known to dramatically exacerbate the symptoms of schizophrenia $[1,13,14]$. In a randomized, double-blind, placebo-controlled study, Krystal and coworkers [15] reported that the non-competitive NMDA receptor antagonist ketamine (Fig. 2) produced positive and negative symptoms in a dose-dependent manner. A high dose of ketamine elicited significant perceptual effects, including altered perceptions of the body, environment, and time. In another double-blind, placebo-controlled study, Malhotra et al. [16] reported that ketamine produced brief psychosis marked by thought disorder and withdrawalretardation in healthy volunteers. Furthermore, a doubleblind, crossover-design study revealed that ketamine alters mood in healthy volunteers [17]. Moreover, in a doubleblind, placebo-controlled study, Lahti et al. [18] reported that ketamine induced a brief (less than 30 minutes), doserelated worsening of positive symptoms in schizophrenic patients maintained on haloperidol. In contrast, Zarate et al. [19] demonstrated the robust and rapid (within $2 \mathrm{~h}$ ) antidepressant effects of a single dose of ketamine $(0.5$

*Address correspondence to this author at the From the Division of Clinical Neuroscience, Chiba University Center for Forensic , Mental Health, 1-8-1 Inohana, Chiba 260-8670, Japan; Tel: +81-43-226-2147,

Fax: +81-43-226-2150; Email: hashimoto@ faculty.chiba-u.jp $\mathrm{mg} / \mathrm{kg}$, i.v. infusion for $40 \mathrm{~min}$ ) in treatment-resistant major depression, suggesting the role of NMDA receptors in the rapid antidepressant activity of ketamine [20-22].

In addition to glutamate, the NMDA receptors are modulated by glycine, D-serine, polyamines, and specific divalent cations, including magnesium and zinc [9-12] (Fig. 1). Glycine and D-serine (Fig. 3) act as obligatory coagonists at the glycine modulatory sites on the NMDA receptors to regulate glutamatergic transmission. Currently, the glycine modulatory sites on the NMDA receptors are the most attractive therapeutic targets for schizophrenia. This review article provides an overview of glycine transporter-1 (GlyT-1) inhibitors as a potential therapeutic approach to the treatment of schizophrenia.

\section{GLYCINE}

Glycine (Fig. 3) was first proposed to act as a neurotransmitter in the mammalian spinal cord in 1965 [23]. Glycine is now among the well-characterized amino acid neurotransmitters in the mammalian CNS, where it is known to act as an inhibitory transmitter via its interaction with strychnine-sensitive glycine receptors [24-29]. It also plays an important role in excitatory neurotransmission via strychnine-insensitive glycine sites located on the NMDA receptors [26-29].

The plasma levels of total serine (L- and D-serine) and glycine in patients with schizophrenia are higher than those of controls [30], and the levels of serine and glycine in the brains of schizophrenic patients are higher than those of controls [30,31], suggesting a possible abnormality in serine hydroxymethyltransferase, by which glycine is converted to L-serine [10]. Interestingly, it has been reported that serum D-serine levels and the D-serine/total serine ratio in patients with schizophrenia are significantly lower than those of 


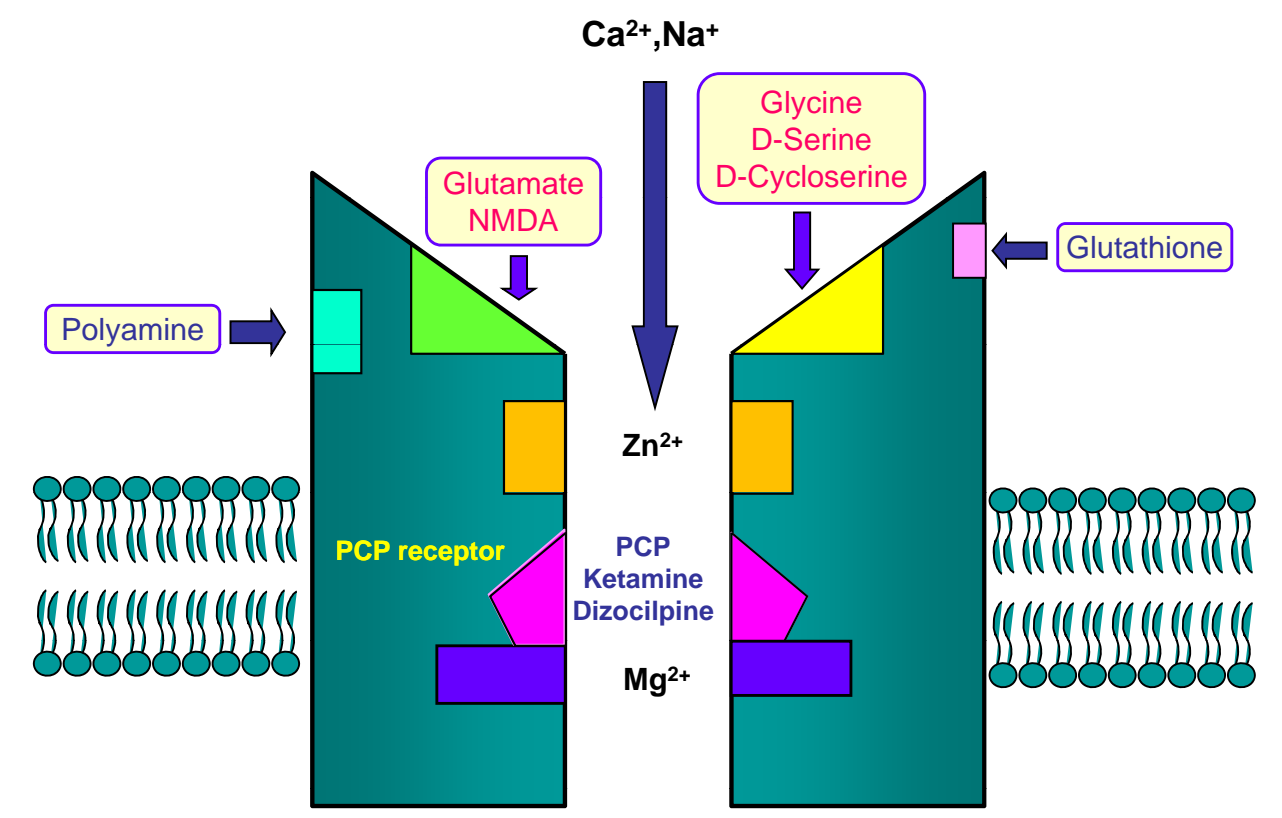

Fig. (1). The NMDA receptor complex Glutamate and NMDA bind to the agonist site on NMDA receptors. Phencyclidine (PCP), ketamine, and dizocilpine $((+)-\mathrm{MK}-801)$ bind to PCP-receptor in the inside of the NMDA receptors. Glycine and D-serine bind to co-agonist site (glycine modulatory site) on the NMDA receptors.

healthy control subjects, supporting the hypothesis of NMDA receptor hypofunction in schizophrenia [8].<smiles>c1ccc(C2(N3CCCCC3)CCCCC2)cc1</smiles>

Phencyclidine (PCP)<smiles>CNC1(c2ccccc2)CCCCC1=O</smiles>

Ketamine

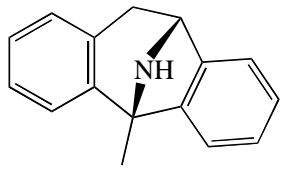

Dizocilpine ((+)MK-801)

Fig. (2). Chemical structures of phencyclidine (PCP), ketamine, and dizocilpine ((+)-MK-801).

Given the NMDA receptor hypofunction hypothesis of schizophrenia, increasing NMDA receptor function by glycine may be a potential strategy for the management of schizophrenia. Recent retrospective analyses have suggested that NMDA receptor agonists are effective at the treatment of persistent negative symptoms and cognitive deficits of schizophrenia, and that the full agonist glycine may be more effective than the partial agonist D-cycloserine (Fig. 3) [32].

\section{GLYCINE TRANSPORTER (GLyT)}

In the CNS, synaptic levels of glycine are regulated by specific sodium/chloride-dependent transporters. The effects of glycine in the synapse are terminated by its rapid reuptake into the nerve terminal and adjacent glial cells via highaffinity glycine transporters referred to as GlyT-1 and GlyT2. GlyT-1 and GlyT-2 possess 12 putative transmembrane spanning domains, and share approximately $50 \%$ amino acid sequence identity [26-29,33,34]. GlyT-1 is widely expressed in the CNS, where it is predominantly present on glial cells. It is likely that GlyT-1 is responsible for glycine reuptake in forebrain areas, and in some regions, it may be co-localized with strychnine-insensitive glycine modulatory sites on the NMDA receptors [33-39]. A recent study demonstrated that glycine transport might maintain local synaptic glycine at very low levels, suggesting that GlyT-1 could play a role in regulating glutamatergic neurotransmission via NMDA receptors [40]. In contrast to GlyT-1, GlyT-2 has a predominantly neuronal and more limited distribution, being primarily restricted to the spinal cord, brainstem, and cerebellum [38]. Indeed, GlyT-2 is known to be co-localized with strychnine-sensitive glycine receptors, suggesting that GlyT-2 may be a reliable marker for glycinergic neurons [26-29].<smiles>NCC(=O)O</smiles>

Glycine<smiles>CNCC(=O)O</smiles>

Sarcosine (N-Methylglycine)<smiles>N[C@@H]1CONC1=O</smiles>

D-Cycloserine
Fig. (3). Chemical structures of glycine, sarcosine ( $N$-methyl glycine), D-serine, and D-cycloserine 
In an attempt to clarify the in vivo functional roles of glycine transporters in the CNS, knockout mice deficient in the GlyT-1 gene have been generated [41,42]. Newborn mice deficient in the GlyT-1 gene are anatomically normal, but show severe motor and respiratory deficits and die during the first postnatal day [41]. Glycine or the GlyT-1 inhibitor sarcosine ( $N$-methyl glycine; Fig. 3) were found to suppress respiratory activity in slices from wild-type mice. During early postnatal life, GlyT-1 is essential for regulating glycine levels at inhibitory glycine receptors, and GlyT-1 deletion generates symptoms found in human glycine encephalopathy [41]. Furthermore, heterozygous knockout mice (reduced expression of GlyT-1) show enhanced hippocampal NMDA receptor function and memory retention, and are protected against disruptions of sensory gating induced by amphetamine, which suggests that GlyT-1 inhibitors might bring about both cognitive enhancement and antipsychotic effects [42]. Mice heterozygous for the GlyT-1 gene show faster decay kinetics, reduced ifenprodil sensitivity, and increased zinc-induced antagonism in NMDA receptor currents [42]. These findings highlight the importance of GlyT-1 in the regulation of glutamatergic neurotransmission. Taken together, the data suggest that increasing synaptic levels of glycine by inhibition of its uptake will lead to enhanced NMDA receptor activation, in turn suggesting a potential role for GlyT-1 inhibitors as a novel treatment for schizophrenia [43-55].

\section{GLyT-1 INHIBITORS}

Glycine is an endogenous compound that is actively metabolized and sequestered in the brain. Glycine is extensively metabolized in the liver, and only poorly crosses the blood-brain barrier. Therefore, a large amount of glycine is needed for the treatment of schizophrenia [32]. Thus, the ability of glycine levels to modulate NMDA receptormediated neurotransmission suggests that the pharmacological manipulation of synaptic glycine might be effective in the treatment of conditions involving NMDA receptor hypofunction [1,43-55].

The NMDA receptor antagonist PCP (Fig. 2) has been widely used in studies of animal models of schizophrenia [9$11,56,57]$. We previously reported that repeated administration of PCP $(10 \mathrm{mg} / \mathrm{kg} / \mathrm{day}$ for 10 days $)$ caused long-term cognitive deficits in mice (more than 6 weeks after the final administration of $\mathrm{PCP}$ ), and that PCP-induced

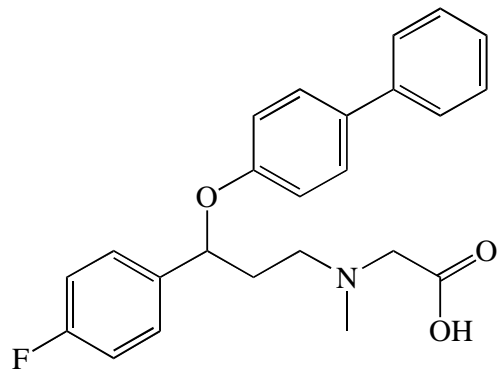

NFPS (ALX 5407)

Fig. (4). Chemical structure of $(R)-(N-[3-(4 '-f l u o r o p h e n y l)-3-(4 '-$ phenylphenoxy)propyl])sarcosine (NFPS, ALX 5407). cognitive deficits could be improved by subsequent subchronic ( 2 weeks) administration of clozapine, but not haloperidol [58]. Therefore, the reversal of PCP-induced cognitive deficits may be a potential animal model of atypical antipsychotic activity, i.e., this model may be beneficial in terms of ameliorating the cognitive deficits in people with schizophrenia [59-67]. Using this model, we reported that treatment with the selective GlyT-1 inhibitor, $(R)$-(N-[3-(4'-fluorophenyl)-3-(4'-phenylphenoxy)propyl])sarcosine (NFPS, ALX 5407; Fig. 4) [68-71], attenuated PCPinduced cognitive deficits in mice [64]. We also found that repeated administration of PCP caused increased levels of GlyT-1 protein in the mouse hippocampus, and that extracellular glycine levels in the hippocampus of PCPtreated mice were lower than those of control mice [64]. Furthermore, NFPS inhibited PCP-induced hyperactivity in mice, and NFPS reversed PCP-induced changes in electroencephalogram (EEG) power spectra in conscious rats [71]. It has been reported that NFPS induced a pattern of cFos immunoreactivity comparable with the atypical antipsychotic drug clozapine, and that NFPS enhanced prepulse inhibition (PPI) of the acoustic startle response in DBA/2J mice, a strain with low basal levels of PPI [72]. Moreover, to the same degree as by clozapine or D-serine, NFPS was able to reverse persistent latent inhibition (LI) [72] and cognitive deficits [73] induced by the NMDA receptor antagonist dizocilpine ((+)-MK-801; Fig. 2). Manahan-Vaughan et al. [74] reported that NFPS could rescue hippocampal long-term potentiation and learning deficits in freely behaving rats after systemic administration of dizocilpine. All these findings suggest that GlyT-1 inhibitors could potentially serve as therapeutic drugs to treat the cognitive deficits associated with schizophrenia.

Researchers at Sanofi-Synthelabo Recherche reported the detailed neuropharmacological profile of SSR 504734 (Fig. 5) as part of a biochemical approach to developing a selective and reversible GlyT-1 inhibitor [75]. SSR 504734, a selective and reversible inhibitor of GlyT-1, blocked the ex vivo uptake of glycine in a rapid, reversible, and long-term manner. In animal models of schizophrenia, this compound normalized spontaneous PPI deficits in DBA/2 mice, and reversed both amphetamine-induced locomotor hyperactivity as well as selective attention deficits in adult rats treated neonatally with PCP. These findings suggest that SSR 504734 is a potent and selective GlyT-1 inhibitor that exhibits ameliorative effects in animal models of schizophrenia; this compound may therefore be efficacious not only in treating positive, but also negative symptoms (i.e., cognitive deficits) of schizophrenia [75]. Moreover, it has been reported that SSR $504734(10 \mathrm{mg} / \mathrm{kg})$ enhanced the facilitatory influence of glutamatergic afferents on dopamine neurotransmission in the nucleus accumbens, and this synergistic effect was found to be dependent on glutamatergic tone [76]. Furthermore, SSR 504734 is reported to be effective in the PCP-induced functional activation in the cortico-limbo-thalamic circuits [77] and working memory deficits [78]. Moreover, SSR 504734 attenuated PCP-induced hyperlocomotion in mice, but potentiated the motor stimulant and motor depressant effects of amphetamine and apomorphine, respectively [79]. 
<smiles>O=C(N[C@H](c1ccccc1)[C@H]1CCCCN1)c1cccc(Cl)c1Cl</smiles>

SSR 504734

Fig. (5). Chemical structure of SSR 504734

Recently, researchers at the Sanofi-Synthelabo Recherche Institute reported the detailed neuropharmacological profile of SSR 103800, a novel selective and reversible GlyT-1 inhibitor. They demonstrated that SSR 103800 elevates central glycine levels in the prefrontal cortex, and it exhibits potential therapeutic activity in animal models considered representative of the positive, cognitive, and depressive symptoms observed in patients with schizo- phrenia [80]. SSR 103800 ( 1 and $3 \mathrm{mg} / \mathrm{kg}$ ) and SSR 504734 (1 and $10 \mathrm{mg} / \mathrm{kg}$ ) potentiated latent inhibition (LI) under conditions where LI was not present in non-treated controls and SSR $103800(1 \mathrm{mg} / \mathrm{kg})$ reversed amphetamine-induced disrupted LI while not affecting LI on its own. Additionally, SSR 103800 ( 1 and $3 \mathrm{mg} / \mathrm{kg}$ ) and SSR 504734 (3 and 10 $\mathrm{mg} / \mathrm{kg}$ ) reversed abnormally persistent LI induced by dizocilpine. In the neurodevelopmental model, SSR 504734 ( 3 and $10 \mathrm{mg} / \mathrm{kg}$ ) reverted the LI back to control (normal) levels [78]. These preclinical data from acute and neurodevelopmental models suggest that GlyT-1 inhibitors could exhibit activity in the positive, negative, and cognitive symptom domains of schizophrenia.

Researchers at Merck Research Laboratories reported the pharmacological profile of a class of novel GlyT-1 inhibitors related to 4,4-disubstituted piperidines, including 2methoxy- $N$-\{1-[4-phenyl-1-(propylsulfonyl)piperidin-4-yl]methyl benzamide (compound 1: Fig. 6) and 2-amino-6chloro- $N$ - $\{(1 S)$-1-[4-phenyl-1-(propylsulfonyl)-piperidin-4yl]ethyl \}benzamide (compound 2: Fig. 6) [81,82]. A rapid and sustained increase in the extracellular levels of glycine in the prefrontal cortex of freely moving rats was observed at

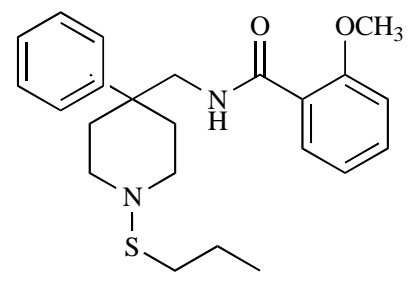

Compound 1<smiles>CCCSN1CCC(c2ccccc2)([C@@H](C)NC(=O)c2c(N)cccc2Cl)CC1</smiles>

Compound 2

Fig. (6). Chemical structure of compound 1 (2-methoxy- $N$-\{[4-phenyl-1-(propylthio)piperidin-4-yl]methyl $\}$ benzamide) and compound 2 (2amino-6-chloro- $N$ - $\{(1 S)$-1-[4-phenyl-1-(propylthio)piperidin-4-yl]ethyl $\}$ benzamide).<smiles>O=C1NCN(c2ccccc2)C12CCN([C@H]1CCCC[C@H]1c1ccccc1)CC2</smiles>

Compound 3<smiles>O=C1NCN(c2ccccc2)C12CCN([C@@H]1CCCC[C@]1(O)c1ccccc1)CC2</smiles>

Compound 4<smiles>O=C1NC[C@H](c2ccccc2)C12CCN([C@@H]1CCCC[C@H]1c1ccccc1)CC2</smiles>

Compound 5<smiles>O=C1NC[C@H](c2ccccc2)C12CCN([C@@H]1CCCC[C@]1(O)c1ccccc1)CC2</smiles>

Compound 6<smiles>O=C1NCC(c2ccc(F)cc2)C12CCN(C1(c3ccc(F)cc3)CCCCC1)CC2</smiles>

Compound 7

Fig. (7). Chemical structures of compound 3, (1-phenyl-8-[(1S,2S)-2-phenylcyclohexyl]-1,3,8-triazaspiro[4.5]decan-4-one), compound 4, (8$[(1 S, 2 R)$-2-hydroxy-2-phenylcyclohexyl]-1-phenyl-1,3,8-triazaspiro[4.5]decan-4-one), compound 5, ((4R)-4-phenyl-8-[(1S,2S)-2phenylcyclohexyl]-2,8-diazaspiro[4.5]decan-1-one), compound $\quad 6, \quad((4 R)-8$-[(1S,2R)-2-hydroxy-2-phenylcyclohexyl]-4-phenyl-2,8diazaspiro[4.5]decan-1-one), and compound 7, (4-(4-fluorophenyl)-8-[1-(4-fluorophenyl)cyclohexyl]-2,8-diazaspiro[4.5]decan-1-one). 
all three experimental doses $(1,3,10 \mathrm{mg} / \mathrm{kg}$, s.c.) of this compound. Furthermore, this compound was found to significantly enhance PPI at three different doses (3, 30, 100 $\mathrm{mg} / \mathrm{kg}$, s.c.) in DBA/2J mice. Brain levels of this compound ranged from $400 \mathrm{nM}$ to $2300 \mathrm{nM}$ during the time course of the PPI experiments. By selectively increasing extracellular glycine levels in the prefrontal cortex via the inhibition of GlyT-1, this compound significantly enhanced performance in a behavioral animal model of sensorimotor gating [81].

Researchers at F. Hoffmann-La Roche, Ltd. reported a novel series of $N$-(2-aryl-cyclohexyl) substituted spiropiperidines (compound 3-7: Fig. 7) as highly selective GlyT-1 inhibitors [83-87]. Furthermore, a potent and selective GlyT-1 inhibitor 4-(4-\{[2-(cyclopropylmethoxy)-5(methylsulfonyl)phenyl]carbonyl $\}$ piperazin-1-yl)-3-

fluorobenzonitrile (compound 8: $\mathrm{EC}_{50}=16 \mathrm{nM}$ for GlyT1)(Fig. 8) increased extracellular glycine levels in the mouse striatum after oral administration [88].

Researchers at $H$. Lundbeck A/S developed the compound (R)-4-[5-chloro-2-(4-methoxy-phenylsulfanyl)phenyl]-2-methyl-piperazin-1-yl-acetic acid (compound 9: $\mathrm{IC}_{50}=150 \mathrm{nM}$ ) (Fig. 9), which was shown to elevate extracellular glycine levels in the rat ventral hippocampus, as measured by in vivo microdialysis at doses of $1.2-4.6 \mathrm{mg} / \mathrm{kg}$ (s.c.) [89]. Furthermore, the same group reported the new compound $(S)-1-\{2-[3-(3-f l u o r o-p h e n y l s u l f a n y l) b i p h e n y l-4-$ yloxy] thyl $\}$ pyrrolidine-2-carboxylic acid (compound 10: $\mathrm{IC}_{50}=59 \mathrm{nM}$ ) [90] (Fig. 9). In vitro and in vivo assessments revealed that the CNS utility of this class of compounds might be diminished due to active efflux transporter activity [90].

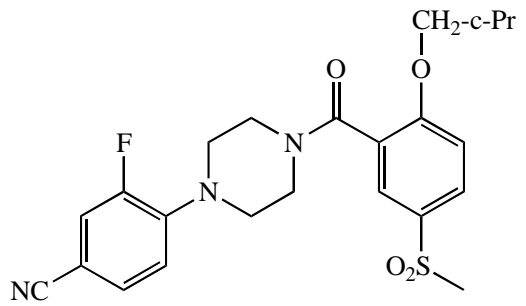

Compound 8

Fig. (8). Chemical structure of compound 8, 4-(4-\{[2(cyclopropylmethoxy)-5-(methylsulfonyl)phenyl]carbonyl \}piperazin-1-yl)-3-fluorobenzonitrile.

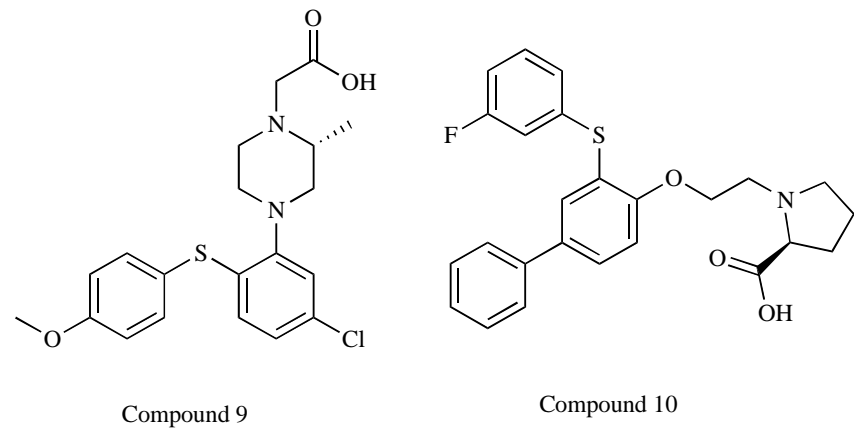

Fig. (9). Chemical structure of compound 9, $(R)-4-[5-c h l o r o-2-(4-$ methoxy-phenylsulfanyl)-phenyl]-2-methyl-piperazin-1-yl-acetic acid and compound 10, (S)-1-\{2-[3-(3-fluoro-phenylsulfanyl) biphenyl-4-yloxy]ethyl \}pyrrolidine-2-carboxylic acid.
ORG 25935 (cis- $N$-methyl- $N$-(6-methoxy-1-phenyl-1,2,3,4tetrahydronaphthalen-2- ylmethyl)amino-methylcarboxylic acid hydrochloride)( Fig. 10) is a GlyT-1 inhibitor that easily crosses the blood-brain barrier. ORG 25935 (6 mg/kg, i.p.) was shown to increase striatal extracellular glycine levels by $\sim 50-80 \%$ for $\sim 2.5$ hours [91]. Molander et al. [92] reported that ORG 25935 decreased ethanol intake and ethanol preference, as compared with vehicle, without affecting water intake. This effect was dose-dependent, developed gradually, and was sustained for up to 40 days, even after the introduction of an alcohol-deprivation period. The findings suggest that ORG 25935, and possibly other GlyT-1 inhibitors as well, could provide a new pharmacological treatment strategy for alcohol dependence or abuse [92].<smiles>COc1ccc2c(c1)CC[C@@H](CN(C)CC(=O)O)[C@H]2c1ccccc1</smiles>

Fig. (10). Chemical structure of ORG 25935

\section{BRAIN IMAGING OF GLYT-1 IN THE BRAIN}

The distribution, density, and activity of GlyT-1 in the living human brain can be visualized noninvasively by the specific radioligands and positron emission tomography (PET), and single photon computed tomography (SPECT), and the receptor binding can be quantified by appropriate tracer kinetic models, which can be modified and simplified for particular applications. Therefore, in vivo PET/SPECT imaging of GlyT-1 in the human brain provides a method for quantitative study of the GlyT-1-related pathophysiology in schizophrenia. Researchers at Merck developed the novel radioligand $\quad\left[{ }^{35} \mathrm{~S}\right](S)$-2-amino-4-chloro- $N$-(1-(4-phenyl-1(propylsulfonyl)piperidin-4-yl)ethyl)benzamide $\quad\left(\left[{ }^{35} \mathrm{~S}\right] \mathrm{AC}\right.$ PPB: $\mathrm{Kd}=1.9 \mathrm{nM}$ ) (Fig. 11) for GlyT-1 in the brain. Autoradiographic studies of rat and rhesus brain slices with $\left[{ }^{35} \mathrm{~S}\right] \mathrm{ACPPB}$ showed that specific binding sites were plentiful and nonhomogeneously distributed, with high levels of binding in the brainstem, cerebellar white matter, thalamus, cortical white matter and spinal cord gray matter. In vivo studies demonstrated displaceable binding of $\left[{ }^{35} \mathrm{~S}\right] \mathrm{ACPPB}$ in rat brain tissues following intravenous administration of this radioligand [93]. Investigators at Merck also developed the novel PET ligand $\left[{ }^{18} \mathrm{~F}\right]$ 2,4dichloro- $N$ - ((1-(propylsulfonyl)-4-(6-fluoropyridin-2-yl) piperidin-4-yl)methyl)benzamide (CFPyPB) (Fig. 11) for GlyT-1 in the human brain [94].

In addition, researchers at Glaxo developed the PET ligand $\left[{ }^{11} \mathrm{C}\right] \mathrm{GSK} 931145$ (Fig. 12) for GlyT-1 in the human brain $[95,96] .\left[{ }^{18} \mathrm{~F}\right] \mathrm{CFPyPB}$ and $\left[{ }^{11} \mathrm{C}\right] \mathrm{GSK} 931145$ would be potential PET ligands for in vivo visualization of GlyT-1 in the living human brain with PET. These PET ligands represent a new tool for the evaluation of glutamatergic neurotransmission in the pathophysiology of neuropsychiatric diseases, including schizophrenia. 


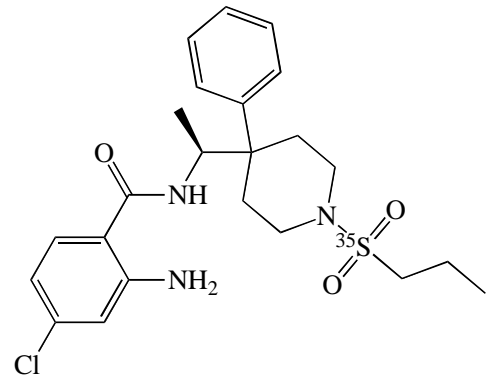

$\left.{ }^{35} \mathrm{~S}\right] \mathrm{ACPPB}$

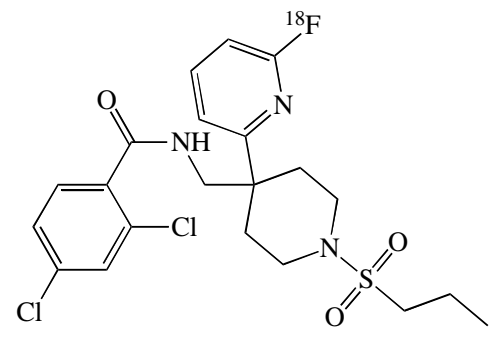

$\left[{ }^{18} \mathrm{~F}\right] \mathrm{CFPyPB}$

Fig. (11). Chemical structures of $\left.{ }^{35} \mathrm{~S}\right](\mathrm{S})-2$-amino-4-chloro-N-(1(4-phenyl-1-(propylsulfonyl)piperidin-4-yl)ethyl)benzamide $\left(\left[{ }^{35} \mathrm{~S}\right]\right.$ $\mathrm{ACPPB})$, and $\left[{ }^{18} \mathrm{~F}\right]$ 2,4-dichloro-N- ((1-(propylsulfonyl)-4-(6fluoropyridin-2-yl) piperidin-4-yl)methyl)benzamide $\left(\left[{ }^{18} \mathrm{~F}\right] \mathrm{CFPy}\right.$ $\mathrm{PB})$.

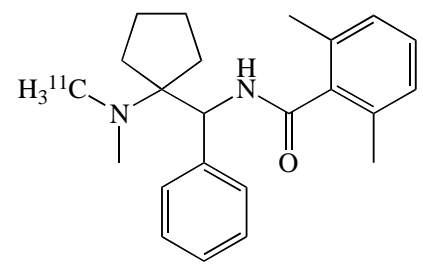

$\left[{ }^{11} \mathrm{C}\right]$ GSK 931145

Fig. (12). Chemical structure of $\left[{ }^{11} \mathrm{C}\right] \mathrm{GSK} 931145$.

\section{CLINICAL STUDY OF GLYT-1 INHIBITORS}

Sarcosine is generated by the enzymatic transfer of a methyl group from $S$-adenosylmethionine to glycine, and this reaction is catalyzed by the enzyme glycine $N$ methyltransferase [97,98]. Recently, sarcosine was identified as a biomarker that is highly increased during prostate cancer progression to metastasis and can be detected non-invasively in urine [99]. Interestingly, a recent population-based, nested, case-controlled study demonstrated a $40.7 \%$ lower risk of prostate cancer in male patients with schizophrenia [100]. It is thus likely that the sarcosine pathway plays a role in the lower risk for prostate cancer in male subjects with schizophrenia, although further detailed studies will be necessary to confirm this hypothesis [98].

Sarcosine is a safe drug, since it is synthesized in the human body. In fact, treatment with sarcosine ( 2 g/day) can benefit schizophrenic patients also being treated with antipsychotics, including risperidone [101], but not clozapine [102]. A randomized, double-blind, placebo-controlled study demonstrated that members of a sarcosine ( $2 \mathrm{~g} /$ day $)$ group showed greater reductions in their Positive and Negative Syndrome Scale (PANSS) total scores than members of a placebo group or D-serine ( $2 \mathrm{~g} /$ day) group, suggesting that sarcosine is superior to $\mathrm{D}$-serine in that benefits both patients with long-term stable disease and also acutely ill persons with schizophrenia [103]. Furthermore, a randomized, double-blind study reported that sarcosine $(2 \mathrm{~g} /$ day $)$ alone was effective in the treatment of acutely symptomatic drugfree patients with schizophrenia [104]. Further large-sized, placebo-controlled, dose-finding studies are needed to fully assess the effects of sarcosine, since these reports regarding the beneficial effects of sarcosine were based on small studies from the same group in Taiwan. In contrast, Zhang et al. [105] reported that sarcosine is an NMDA receptor coagonist that differs from glycine, suggesting that co-agonistic activity at the NMDA receptors of sarcosine may, in part, be involved in the clinical benefits of this drug in schizophrenia. Nonetheless, all these findings suggest that GlyT-1 inhibition could be a novel pharmacotherapeutic target for enhancing NMDA receptor function.

Very recently, Liem-Moolenaar et al. [106] reported the effects of the GlyT-1 inhibitor R 231857 (Fig. 13) on the CNS and on scopolamine-induced impairments in cognitive and psychomotor function in healthy subjects. R231857 had some small effects on scopolamine-induced CNSimpairment, which were also not clearly dependent on dose. Scopolamine proved to be an accurate, reproducible and safe model for the induction of CNS impairment by an anticholinergic mechanism. R231857 lacked consistent doserelated effects in this study, probably because the CNS concentrations were too low to produce significant/reproducible CNS effects or to affect the scopolamine challenge in healthy volunteers. The effects of higher doses in healthy volunteers and the clinical efficacy in patients remain to be established. To date, clinical findings with GlyT-1 inhibitors are limited because of the early stage of development of the most high-affinity compounds.<smiles>CN(C/C=C(/c1ccc(-c2ccco2)cc1)c1ccsc1)CC(=O)O</smiles>

R 231857

Fig. (13). Chemical structure of R231857.

\section{CONCLUDING REMARKS}

As described above, the glycine modulatory sites on NMDA receptors are among the most attractive targets for developing potential therapeutic drugs for the treatment of schizophrenia. One means of enhancing NMDA receptor function would be to pharmacologically increase synaptic glycine levels by GlyT-1 inhibitors. At present, a number of pharmaceutical companies are developing novel and 
selective GlyT-1 inhibitors for the treatment of schizophrenia [43-55]. Gaining a better understanding of the role of GlyT-1 in the treatment of schizophrenia is expected to provide new perspectives for treating this disorder. Finally, the pharmacological modulation of glycine modulatory sites on NMDA receptors by non-sarcosinederived GlyT-1 inhibitors could be beneficial in the treatment of the cognitive deficits and psychosis associated with several psychiatric diseases, including schizophrenia.

\section{ACKNOWLEDGEMENTS}

This study was supported in part by a grant from the Minister of Education, Culture, Sports, Science, and Technology of Japan (to K.H.), and by a grant from the Program for Promotion of Fundamental Studies in Health Sciences of the National Institute of Biomedical Innovation of Japan (to K.H.).

\section{REFERENCES}

[1] Javitt, D. C.; Zukin, S. R. Recent advances in the phencyclidine model of schizophrenia. Am. J. Psychiatry, 1991, 148, 1301-1308.

[2] Olney, J. W.; Farber, N. B. Glutamate receptor dysfunction and schizophrenia. Arch. Gen. Psychiatry, 1995, 52, 998-1007.

[3] Coyle, J.T. The glutamatergic dysfunction hypothesis for schizophrenia. Harv. Rev. Psychiatry, 1996, 3, 241-253.

[4] Krystal, J. H.; D'Souza, D. C.; Petrakis, I. L.; Belger, A.; Berman, R. M.; Charney, D. S.; Abi-Saab, W.; Madonick, S. NMDA agonists and antagonists as probes of glutamatergic dysfunction and pharmacotherapies in neuropsychiatric disorders. Harv. Rev. Psychiatry, 1999, 7, 125-143.

[5] Goff, D. C.; Coyle, J. T. The emerging role of glutamate in the pathophysiology and treatment of schizophrenia. Am. J. Psychiatry, 2001, 158, 1367-1377.

[6] Tsai, G.; Coyle, J. T. Glutamatergic mechanisms in schizophrenia. Annu. Rev. Pharmacol. Toxicol., 2002, 42, 165-179.

[7] Coyle, J. T.; Tsai, G. The NMDA receptor glycine modulatory site: a therapeutic target for improving cognition and reducing negative symptoms in schizophrenia. Psychopharmacology, 2004, 174, 3238 .

[8] Hashimoto, K.; Fukushima, T.; Shimizu, E.; Komatsu, N.; Watanabe, H.; Shinoda, N.; Nakazato, M.; Kumakiri, C.; Okada, S.; Hasegawa, H.; Imai, K.; Iyo, M. Decreased serum levels of Dserine in patients with schizophrenia: evidence in support of the NMDA receptor hypofunction hypothesis of schizophrenia. Arch. Gen. Psychiatry, 2003, 60, 572-576.

[9] Hashimoto, K.; Okamura, N.; Shimizu, E.; Iyo, M. Glutamate hypothesis of schizophrenia and approach for possible therapeutic drugs. Curr. Med. Chem. - CNS Agents, 2004, 4, 147-154.

[10] Hashimoto, K.; Shimizu, E.; Iyo, M. Dysfunction of glia-neuron communication in pathophysiology of schizophrenia. Curr. Psychiatry Rev., 2005, 1, 151-163.

[11] Hashimoto, K. The NMDA receptor hypofunction hypothesis for schizophrenia and glycine modulatory sites on the NMDA receptors as potential therapeutic drugs. Clin. Psychopharmacol. Neurosci., 2006, 4, 3-10.

[12] Hashimoto, K.; Hattori, E. Candidate genes and models. Neurotransmission. In: Neurogenetics in Psychiatry: Scientific Understanding and Clinical Applications, Sawa, A., McInnis, M., Eds., Taylor \& Francis Group: New York, 2007; pp. 81-100.

[13] Luby, E. D.; Cohen, B. D.; Rosenbaum, G.; Gottlieb, J. S.; Kelley, R. Study of a new schizophrenomimetic drug; sernyl. AMA Arch. Neurol. Psychiatry, 1959, 81, 363-369.

[14] Allen, R. M.; Young, S. J. Phencyclidine-induced psychosis. Am. J. Psychiatry, 1978, 135, 1081-1084.

[15] Krystal, J. H.; Karper, L. P.; Seibyl, J. P.; Freeman, G. K.; Delaney, R.; Bremner, J. D.; Heninger, G.. R.; Bowers, M. B. Jr; Charney, D. S. Subanesthetic effects of the noncompetitive NMDA antagonist, ketamine, in humans. Psychotomimetic, perceptual, cognitive, and neuroendocrine responses. Arch. Gen. Psychiatry, 1994, 51, 199-214.

[16] Malhotra, A. K.; Pinals, D. A.; Weingartner, H.; Sirocco, K.; Missar, C. D.; Pickar, D.; Breier, A. NMDA receptor function and human cognition: the effects of ketamine in healthy volunteers. Neuropsychopharmacology, 1996, 14, 301-307.

[17] Hartvig, P.; Valtysson, J.; Lindner, K.J.; Kristensen, J.; Karlsten, R.; Gustafsson, L.L.; Persson, J.; Svensson, J. O.; Oye, I.; Antoni, G. Central nervous system effects of subdissociative doses of $(S)$ ketamine are related to plasma and brain concentrations measured with positron emission tomography in healthy volunteers. Clin. Pharmacol. Ther., 1995, 58, 165-173.

[18] Lahti, A. C.; Koffel, B.; LaPorte, D.; Tamminga, C. A. Subanesthetic doses of ketamine stimulate psychosis in schizophrenia. Neuropsychopharmacology, 1995, 13, 9-19.

[19] Zarate Jr, C. A.; Singh, J. B.; Carlson, P. J.; Brutsche, N. E.; Ameli, R.; Luckenbaugh, D. A.; Charney, D. S.; Manji, H. K. A randomized trial of an $N$ - methyl-D-aspartate antagonist in treatment-resistant major depression. Arch. Gen. Psychiatry, 2006 63, 856-864.

[20] Maeng, S.; Zarate, C. A. The role of glutamate in mood disorders: results from the ketamine in major depression study and the presumed cellular mechanism underlying its antidepressant effects. Curr. Psychiatry Rep., 2007, 9, 467-474.

[21] Machado-Vieira, R.; Salvadore, G.; Diazgranados, N.; Zarate, C. A. Jr. Ketamine and the next generation of antidepressants with a rapid onset of action. Pharmacol. Ther., 2009, 123, 143-150.

[22] Hashimoto, K. Emerging role of glutamate in the pathophysiology of major depressive disorder. Brain Res. Rev., 2009, 61, 105-123.

[23] Aprison, M.H.; Werman, R. The distribution of glycine in cat spinal cord and roots. Life Sci., 1965, 4, 2075-2083.

[24] Curtis, D. R.; Hosli, L.; Johnston, G.. A. Inhibition of spinal neurons by glycine. Nature, 1967, 215, 1502-1503.

[25] Semba, T.; Kano, M. Glycine in the spinal cord of cats with local tetanus rigidity. Science, 1969, 164, 571-572.

[26] Aragon, C.; Lopez-Corcuera, B. Glycine transporters: crucial roles of pharmacological interest revealed by gene deletion. Trends Pharmacol. Sci., 2005, 26, 283-286.

[27] Eulenburg, V.; Armsen, W.; Betz, H.; Gomeza, J. Glycine transporters: essential regulators of neurotransmission. Trends Biochem. Sci., 2005, 30, 325-333.

[28] Zafra, F.; Aragon, C.; Gimenez, C. Molecular biology of glycinergic neurotransmission. Mol. Neurobiol., 1997, 14, 117-142.

[29] Danysz, W.; Parsons, A. C. Glycine and $N$-methyl-D-aspartate receptors: physiological significance and possible therapeutic applications. Pharmacol., Rev., 1998, 50, 597-664.

[30] Waziri, R.; Baruah, S.; Hegwood, T. S.; Sherman, A. D. Abnormal serine hydroxymethyl transferase activity in the temporal lobes of schizophrenics. Neurosci. Lett., 1990, 120, 237-40.

[31] Waziri, R.; Baraiah, S.; Sherman, A. D. Abnormal serine-glycine metabolism in the brains of schizophrenics. Schizophrenia Res., 1992, 8, 233-243.

[32] Heresco-Levy, U.; Javitt, D. C. Comparative effects of glycine and D-cycloserine on persistent negative symptoms in schizophrenia: a retrospective analysis. Schizoph. Res., 2004, 66, 89-96.

[33] Smith, K. E.; Borden, L. A.; Hartig, P. R.; Branchek, T.; Weinshank, R. L. Cloning and expression of a glycine transporter reveal colocalization with NMDA receptors. Neuron, 1992, 8, 927 935.

[34] Borowsky, B.; Mezey, E.; Hoffman, B. J. Two glycine transporter variants with distinct localization in the CNS and peripheral tissues are encoded by a common gene. Neuron, 1993, 10, 851-863.

[35] Liu, Q. R.; Lopez-Corcuera, B.; Mandiyan, S.; Nelson, H.; Nelson, N. Molecular characterization of four pharmacologically distinct gamma-aminobutyric acid transporters in mouse brain. J. Biol. Chem., 1993, 268, 2106-2112.

[36] Kim, K. M.; Kingsmore, S. F.; Han, H.; Yang-Feng, T. L.; Godinot, N.; Seldin, M. F.; Caron, M. G.; Giros, B. Cloning of the human glycine transporter type 1: molecular and pharmacological characterization of novel isoform variants and chromosomal localization of the gene in the human and mouse genomes. Mol. Pharmacol., 1994, 45, 608-617. 
[37] Zafra, F.; Aragon, C.; Olivares, L.; Danbolt, N. C.; Gimenez, C.; Storm-Mathisen, J. Glycine transporters are differentially expressed among CNS cells. J. Neurosci., 1995, 15 (5 Pt 2), 3952-3969.

[38] Zafra, F.; Gomeza, J.; Olivares, L.; Aragon, C.; Gimenez, C. Regional distribution and developmental variation of the glycine transporters GLYT1 and GLYT2 in the rat CNS. Eur. J. Neurosci., 1995, 7, 1342-1352.

[39] Cubelos, B.; Gimenez, C.; Zafra, F. Localization of the GLYT1 glycine transporter at glutamatergic synapses in the rat brain. Cereb. Cortex, 2005, 15, 448-459.

[40] Bergeron, R.; Meyer, T. M.; Coyle, J. T.; Greene, R. W. Modulation of $N$-methyl-D-aspartate receptor function by glycine transport. Proc. Natl. Acad. Sci. USA, 1998, 95, 15730-15734.

[41] Gomeza, J.; Hulsmann, S.; Ohno, K.; Eulenburg, V.; Szoke, K.; Richter, D.; Betz, H. Inactivation of the glycine transporter 1 gene discloses vital role of glial glycine uptake in glycinergic inhibition. Neuron, 2003, 40, 785-796.

[42] Tsai, G.; Ralph-Williams, R. J.; Martina, M.; Bergeron, R.; BergerSweeney, J.; Dunham, K. S.; Jiang, Z.; Caine, S. B.; Coyle, J. T. Gene knockout of glycine transporter 1: characterization of the behavioral phenotype. Proc. Natl. Acad. Sci. USA, 2004, 101, 8485-8490.

[43] Vandenberg, R. J.; Aubrey, K. R. Glycine transport inhibitors as potential antipsychotic drugs. Expert Opin. Ther. Targets, 2001, 5, 507-518.

[44] Javitt, D. C. Glycine modulators in schizophrenia. Curr. Opin. Investig. Drugs, 2002, 3, 1067-1072.

[45] Millan, M. J. N-methyl-D-aspartate receptor-coupled glycineB receptors in the pathogenesis and treatment of schizophrenia: a critical review. Curr. Drug Targets CNS Neurol. Disord., 2002, 1, 191-213.

[46] Sur, C.; Kinney, G.. G. The therapeutic potential of glycine transporter-1 inhibitors. Expert Opin. Investig. Drugs, 2004, 13, 515-521.

[47] Kinney, G. G.; Sur, C. Glycine site modulators and glycine transporter-1 inhibitors as novel therapeutic targets for the treatment of schizophrenia. Curr. Neuropsychopharmacol., 2005, $3,35-43$.

[48] Hashimoto, K. Glycine transporter inhibitors as therapeutic agents for schizophrenia. Recent Pat. CNS Drug Discov., 2006, 1, 43-54.

[49] Lechner, S. M. Glutamate-based therapeutic approaches: inhibitors of glycine transport. Curr. Opin. Pharmacol., 2006, 6, 75-81.

[50] Lindsley, C. W.; Wolkenberg, S. E.; Kinney, G. G. Progress in the preparation and testing of glycine transporter type-1 (GlyT-1) inhibitors. Curr. Top. Med. Chem., 2006, 6, 1883-1896.

[51] Hashimoto, K. Glycine transporter-1 inhibitors as novel therapeutic drugs for schizophrenia. CNS Agents Med. Chem., 2007, 7, 177182 .

[52] Javitt, D. C. Glycine transport inhibitors and the treatment of schizophrenia. Biol. Psychiatry, 2008, 63, 6-8.

[53] Yang, C. R.; Svensson, K. A. Allosteric modulation of NMDA receptor via elevation of brain glycine and $\mathrm{D}$-serine: the therapeutic potentials for schizophrenia. Pharmacol. Ther., 2008, 120, 317332 .

[54] Javitt, D. C. Glycine transport inhibitors for the treatment of schizophrenia: symptom and disease modification. Curr. Opin. Drug Discov. Dev., 2009, 12, 468-478.

[55] Hashimoto, K. Glycine transporter inhibitors as therapeutic agents for schizophrenia. Front. CNS Drug Discov., 2009, in press.

[56] Jentsch, J. D.; Roth, R. H. The neuropsychopharmacology of phencyclidine: from NMDA receptor hypofunction to the dopamine hypothesis of schizophrenia. Neuropsychopharmacology, 1999, 20, 201-225.

[57] Morris, B. J.; Cochran, S. M.; Pratt, J. A. PCP: from pharmacology to modelling schizophrenia. Curr. Opin. Pharmacol., 2005, 5, 101106.

[58] Hashimoto, K.; Fujita, Y.; Shimizu, E.; Iyo, M. Phencyclidineinduced cognitive deficits in mice are improved by subsequent subchronic administration of clozapine, but not haloperidol. Eur. J. Pharmacol., 2005, 519, 114-117.

[59] Hashimoto, K.; Fujita, Y.; Ishima, T.; Hagiwara, H.; Iyo, M. Phencyclidine-induced cognitive deficits in mice are improved by subsequent subchronic administration of tropisetron: Role of $\alpha 7$ nicotinic receptors. Eur. J. Pharmacol., 2006, 553, 191-195.
[60] Hashimoto, K.; Fujita, Y.; Iyo, M. Phencyclidine-induced cognitive deficits in mice are improved by subsequent subchronic administration of fluvoxamine: role of sigma-1 receptors. Neuropsychopharmacology, 2007, 32, 514-521.

[61] Hashimoto, K.; Ishima, T.; Fujita, Y.; Matsuo, M.; Kobashi, T.; Takahagi, M.; Tsukada, H.; Iyo, M. Phencyclidine-induced cognitive deficits in mice are improved by subsequent subchronic administration of the novel selective $\alpha 7$ nicotinic receptor agonist SSR180711. Biol. Psychiatry, 2008, 63, 92-97.

[62] Fujita, Y.; Ishima, T.; Kunitachi, S.; Hagiwara, H.; Zhang, L.; Iyo, M.; Hashimoto, K. Phencyclidine-induced cognitive deficits in mice are improved by subsequent subchronic administration of the antibiotic drug minocycline. Prog. Neuropsychopharmacol. Biol. Psychiatry, 2008, 32, 336-339.

[63] Hagiwara, H.; Fujita, Y.; Ishima, T.; Kunitachi, S.; Shirayama, Y.; Iyo, M.; Hashimoto, K. Phencyclidine-induced cognitive deficits in mice are improved by subsequent subchronic administration of the antipsychotic drug perospirone: role of serotonin $5-\mathrm{HT}_{1 \mathrm{~A}}$ receptor. Eur. Neuropsychopharmacol., 2008, 18, 448-454.

[64] Hashimoto, K.; Fujita, Y.; Ishima, T.; Chaki, S.; Iyo, M. Phencyclidine-induced cognitive deficits in mice are improved by subsequent subchronic administration of glycine transporter-1 inhibitor NFPS and D-serine. Eur. Neuropsychopharmacol., 2008, $18,414-421$.

[65] Ishima, T.; Fujita, Y.; Kohno, M.; Kunitachi, S.; Horio, M.; Takatsu, M.; Minase, T.; Tanibuchi, Y.; Hagiwara, H.; Iyo, M.; Hashimoto, K. Improvement of phencyclidine-induced cognitive deficits in mice by subsequent subchronic administration of fluvoxamine, but not sertraline. Open Clin. Chem. J., 2009, 2, 7-11.

[66] Kunitachi, S.; Fujita, Y.; Ishima, T.; Kohno, M.; Horio, M.; Tanibuchi, Y.; Shirayama, Y.; Iyo, M.; Hashimoto, K. Phencyclidine-induced cognitive deficits in mice are improved by subsequent subchronic administration of donepezil: role of sigma-1 receptors. Brain Res., 2009, 279, 189-193.

[67] Tanibuchi, Y.; Fujita, Y.; Kohno, M.; Ishima, T.; Takatsu, Y.; Iyo, M.; Hashimoto, K. Effects of quetiapine on phencyclidine-induced cognitive deficits in mice: a possible role of adrenergic $\alpha 1$ receptors. Eur. Neuropsychopharmacol., 2009, 17, 861-867.

[68] Atkinson, B. N.; Bell, S. C.; De Vivo, M.; Kowalski, L. R.; Lechner, S. M.; Ognyanov, V. I.; Tham, C. S.; Tsai, C.; Jia, J.; Ashton, D.; Klitenick, M. A. ALX 5407: a potent, selective inhibitor of the hGlyT-1 glycine transporter. Mol. Pharmacol., 2001, 60, 1414-1420.

[69] Aubrey, K. R.; Vandenberg, R. J. N-[3-(4'-fluorophenyl)-3-(4'phenylphenoxy)propyl] sarcosine (NFPS) is a selective persistent inhibitor of glycine transport. Br. J. Pharmacol., 2001, 134, 14291436.

[70] Mallorga, P. J.; Williams, J. B.; Jacobson, M.; Marques, R.; Chaudhary, A.; Conn, P. J.; Pettibone, D. J.; Sur, C. Pharmacology and expression analysis of glycine transporter GlyT -1 with $\left[{ }^{3} \mathrm{H}\right]-(N-$ [3-(4'-fluorophenyl)-3-(4'phenylphenoxy)propyl])sarcosine. Neuropharmacology, 2003, 45, 585-593.

[71] Kinney, G. G.; Sur, C.; Burno, M.; Mallorga, P. J.; Williams, J. B.; Figueroa, D. J.; Wittmann, M.; Lemaire, W.; Conn, P. J. The glycine transporter type 1 inhibitor $N$-[3-(4'-fluorophenyl)-3-(4'phenylphenoxy)propyl]sarcosine potentiates NMDA receptormediated responses in vivo and produces an antipsychotic profile in rodent behavior. J. Neurosci., 2003, 23, 7586-7591.

[72] Lipina, T.; Labrie, V.; Weiner, I.; Roder, J. Modulators of the glycine site on NMDA receptors, D-serine and ALX 5407, display similar beneficial effects to clozapine in mouse models of schizophrenia. Psychopharmacology (Berl), 2005, 179, 54-67.

[73] Karasawa, J.; Hashimoto, K.; Chaki, S. D-serine and a glycine transporter inhibitor improve MK-801-induced cognitive deficits in a novel object recognition test in rats. Behav. Brain Res., 2008, 186, 78-83.

[74] Manahan-Vaughan, D.; Wildforster, V.; Thomson, C. Rescue of hippocampal LTP and learning deficits in a rat model of psychosis by inhibition of glycine transporter-1 (GlyT-1). Eur. J. Neurosci., 2008, 28, 1342-1350.

[75] Depoortere, R.; Dargazanli, G.; Estenne-Bouhtou, G.; Coste, A.; Lanneau, C.; Desvignes, C.; Poncelet, M.; Heaulme, M.; Santucci, V.; Decobert, M.; Cudennec, A.; Voltz, C.; Boulay, D.; Terranova, J.P.; Stemmelin, J.; Roger, P.; Marabout, B.; Sevrin, M.; Vige, X.; 
Biton, B.; Steinberg, R.; Francon, D.; Alonso, R.; Avenet, P.; OuryDonat, F.; Perrault, G.; Griebel, G.; George, P.; Soubrie, P.; Scatton, B. Neurochemical, electrophysiological and pharmacological profiles of the selective inhibitor of the glycine transporter-1 SSR504734, a potential new type of antipsychotic. Neuropsychopharmacology, 2005, 30, 1963-1985.

[76] Leonetti, M.; Desvignes, C.; Bougault, I.; Souilhac, J.; Oury-Donat, F.; Steinberg, R. 2-Chloro- $N$-[(S)-phenyl [(2S)-piperidin-2-yl] methyl]-3-trifluoromethyl benzamide, monohydrochloride, an inhibitor of the glycine transporter type 1, increases evokeddopamine release in the rat nucleus accumbens in vivo via an enhanced glutamatergic neurotransmission. Neuroscience, 2006, $137,555-564$

[77] Gozzi, A.; Herdon, H.; Schwarz, A.; Bertani, S.; Crestan, V.; Turrini, G.; Bifone, A. Pharmacological stimulation of NMDA receptors via co-agonist site suppresses fMRI response to phencyclidine in the rat. Psychopharmacology (Berl), 2008, 201, 273-284.

[78] Black, M. D.; Varty, G.. B.; Arad, M.; Barak, S.; De Levie, A.; Boulay, D.; Pichat, P.; Griebel, G.; Weiner, I. Procognitive and antipsychotic efficacy of glycine transport 1 inhibitors (GlyT1) in acute and neurodevelopmental models of schizophrenia: latent inhibition studies in the rat. Psychopharmacology (Berl), 2009; 202, 385-396

[79] Singer P, Feldon J, Yee B. K. Interactions between the glycine transporter 1 (GlyT-1) inhibitor SSR504734 and psychoactive drugs in mouse motor behaviour. Eur. Neuropsychopharmacol., 2009, 19, 571-580.

[80] Boulay, D.; Pichat, P.; Dargazanli, G.; Estenne-Bouhtou, G.; Terranova, J.P.; Rogacki, N.; Stemmelin, J.; Coste, A.; Lanneau, C.; Desvignes, C.; Cohen, C.; Alonso, R.; Vigé, X.; Biton, B.; Steinberg, R.; Sevrin, M.; Oury-Donat, F.; George, P.; Bergis, O.; Griebel, G.; Avenet, P.; Scatton, B. Characterization of SSR103800, a selective inhibitor of the glycine transporter-1 in models predictive of therapeutic activity in schizophrenia. Pharmacol. Biochem. Behav., 2008, 91, 47-58.

[81] Lindsley, C. W.; Zhao, Z.; Leister, W. H.; O'Brien, J.; Lemaire, W.; Williams, D. L. Jr; Chen, T. B.; Chang, R. S.; Burno, M.; Jacobson, M. A.; Sur, C.; Kinney, G.. G.; Pettibone, D. J.; Tiller, P. R.; Smith, S.; Tsou, N. N.; Duggan, M. E.; Conn, P. J.; Hartman, G.. D. Design, synthesis, and in vivo efficacy of glycine transporter-1 (GlyT-1) inhibitors derived from a series of [4-phenyl-1-(propylsulfonyl)piperidin-4-yl]methyl benzamides. ChemMedChem, 2006, $1,807-811$.

[82] Zhao, Z.; O'Brien, J. A.; Lemaire, W.; Williams, D. L. Jr; Jacobson, M. A.; Sur, C.; Pettibone, D. J.; Tiller, P. R.; Smith, S.; Hartman, G. D.; Wolkenberg, S. E.; Lindsley, C. W. Synthesis and SAR of GlyT-1 inhibitors derived from a series of $N$-((4-(morpholine-4carbonyl)-1-(propylsulfonyl)piperidin-4-yl)methyl)benzamides. Bioorg. Med. Chem. Lett., 2006, 16, 5968-5972.

[83] Pinard, E.; Ceccarelli, S. M.; Stalder, H.; Alberati, D. Discovery of $N$-(2-aryl-cyclohexyl) substituted spiropiperidines as a novel class of GlyT-1 inhibitors. Bioorg. Med. Chem. Lett., 2006, 16, 349-353.

[84] Ceccarelli, S. M.; Pinard, E.; Stalder, H.; Alberati, D. Discovery of $N$-(2-hydroxy-2-aryl-cyclohexyl) substituted spiropiperidines as GlyT-1 antagonists with improved pharmacological profile. Bioorg. Med. Chem. Lett., 2006, 16, 354-357.

[85] Alberati, D.; Hainzl, D.; Jolidon, S.; Krafft, E. A.; Kurt, A.; Maier, A.; Pinard, E.; Thomas, A. W.; Zimmerli, D. Discovery of 4substituted-8-(2-hydroxy-2-phenyl-cyclohexyl)-2,8-diaza-spiro [4.5]decan-1-one as a novel class of highly selective GlyT-1 inhibitors with improved metabolic stability. Bioorg. Med. Chem. Lett., 2006, 16, 4311-4315.

[86] Alberati, D.; Ceccarelli, S. M.; Jolidon, S.; Krafft, E. A.; Kurt, A.; Maier, A.; Pinard, E.; Stalder, H.; Studer, D.; Thomas, A. W.; Zimmerli, D. Design and synthesis of 4-substituted-8-(2-phenylcyclohexyl)-2,8-diaza-spiro[4.5]decan-1-one as a novel class of GlyT-1 inhibitors: achieving selectivity against the mu opioid and nociceptin/orphanin FQ peptide (NOP) receptors. Bioorg. Med. Chem. Lett., 2006, 16, 4305-4310.

[87] Alberati, D.; Hainzl, D.; Jolidon, S.; Kurt, A.; Pinard, E.; Thomas, A. W.; Zimmerli, D. 4-Substituted-8-(1-phenyl-cyclohexyl)-2,8diaza-spiro[4.5]decan-1-one as a novel class of highly selective GlyT-1 inhibitors with superior pharmacological and pharmacokinetic parameters. Bioorg. Med. Chem. Lett., 2006, 16, 4321-4325.

[88] Pinard, E.; Alberati, D.; Borroni, E.; Fischer, H.; Hainzl, D.; Jolidon, S.; Moreau, J. L.; Narquizian, R.; Nettekoven, M.; Norcross, R. D.; Stalder, H.; Thomas, A. W. Discovery of benzoylpiperazines as a novel class of potent and selective GlyT1 inhibitors. Bioorg. Med. Chem. Lett., 2008, 18, 5134-5139.

[89] Smith, G.; Ruhland, T.; Mikkelsen, G.; Andersen, K.; Christoffersen, C. T.; Alifrangis, L. H.; Mork, A.; Wren, S. P.; Harris, N.; Wyman, B. M.; Brandt, G. The synthesis and SAR of 2arylsulfanyl-phenyl piperazinyl acetic acids as GlyT-1 inhibitors. Bioorg. Med. Chem. Lett., 2004, 14, 4027-4030.

[90] Smith, G.; Mikkelsen, G.; Eskildsen, J.; Bundgaard, C. The synthesis and SAR of 2-arylsulfanylphenyl-1-oxyalkylamino acids as GlyT-1 inhibitors. Bioorg. Med. Chem. Lett., 2006, 16, 39813984.

[91] Ge, J.; Hamilton, W.; Shahid, M.; Hill, D. R.; Walker, G. The effects of ORG 25935 on the extracellular levels of glycine in brain regions of freely moving rats. Brit. J. Pharmacol., 2001, 133, 135p.

[92] Molander, A.; Lido, H. H.; Lof, E.; Ericson, M.; Soderpalm, B. The glycine reuptake inhibitor ORG 25935 decreases ethanol intake and preference in male Wistar rats. Alcohol Alcohol., 2007, 42, 11-18.

[93] Zeng, Z.; O'Brien, J. A.; Lemaire, W.; O'Malley, S. S.; Miller, P. J.; Zhao, Z.; Wallace, M. A.; Raab, C.; Lindsley, C. W.; Sur, C.; Williams, D. L. Jr. A novel radioligand for glycine transporter 1: characterization and use in autoradiographic and in vivo brain occupancy studies. Nucl. Med. Biol., 2008, 35, 315-325.

[94] Williams, D. L.; Jennings, A.; Lewis, R.; Street, L.; Paten, S.; Wisnoski, D. D.; Wolkenberg, S. E.; Lindsey, C. W.; Zhao, Z.; Krause, S. M.; Ryan, C.; Michener, M. S.; Zeng, Z.; Miller, P. A.; Riffel, K.; O’Malley, S. S.; Sanabria, S.; Eng, W.; Gibson, R. E.; Sur, C.; Cook, J. J.; Hargreaves, R.; Burns, D.; Hamill, T. G. A novel glycine transporter-1 PET tracer: from discovery to clinic. Abstr. Neurosci., 2008, 885.15.

[95] Murthy, N. V.; Passchier, J.; Gunn, R. N.; Searle, G. E.; Bullich, S.; Suarez, M.; Herance, R.; Farre, M.; Herdon, H.; Porter, R.; Sutherland, S.; Faggy, R.; Neve, M.; Slifstein, M.; Laruelle, M.; Catafaur, A.M. $\left[{ }^{11}\right.$ C]GSK 931145: a new PET ligand for glycine transporter 1. Neuroimage, 2008, 41, T21.

[96] Passchier, J.; Murthy, V.; Catafau, A.; Gunn, R.; Gentile, G.; Porter, R.; Herdon, H.; Slifstein, M.; Rabiner, E.; Laruelle, M. Development and evaluation of $\left[{ }^{11} \mathrm{C}\right] \mathrm{GSK}$ 931145, a new PET ligand for imaging type 1 glycine transporters (GlyT1) in the living human brain. J. Nucl. Med., 2008, 49 (Suppl. 1), 129P.

[97] Abate-Shen, C.; Shen, M.M. The Prostate-cancer metabolome. Nature, 2008, 457, 799-800.

[98] Hashimoto, K. Sarcosine and decreased risk for prostate cancer in schizophrenia. Open Clin. Chem. J., 2009, 2, 22-23.

[99] Sreekumar, A.; Poisson, L. M.; Rajendiran, T. M.; Khan, A. P.; Cao, Q.; Yu, J.; Laxman, B.; Mehra, R.; Lonigro, R. J.; Li, Y.; Nyati, M. K.; Ahsan, A.; Kalyana-Sundaram, S.; Han, B.; Cao, X.; Byun, J.; Omenn, G.. S.; Ghosh, D.; Pennathur, S.; Alexander, D. C.; Berger, A.; Shuster, J. R.; Wei, J. T.; Varambally, S.; Beecher, C.; Chinnaiyan, A. M. Metabolomic profiles delineate potential role for sarcosine in prostate cancer progression. Nature, 2009, 457, 910-914.

[100] Hippisley-Cox, J.; Vinogradova, Y.; Coupland, C.; Parker, C. Risk of malignancy in patients with schizophrenia or bipolar disorder. Nested case-control study. Arch. Gen. Psychiatry, 2007, 64, 13681376.

[101] Tsai, G.; Lane, H. Y.; Yang, P.; Chong, M. Y.; Lange, N. Glycine transporter I inhibitor, $N$-methylglycine (sarcosine), added to antipsychotics for the treatment of schizophrenia. Biol. Psychiatry, 2004, 55, 452-456.

[102] Lane, H. Y.; Huang, C. L.; Wu, P. L.; Liu, Y. C.; Chang, Y. C.; Lin, P. Y.; Chen, P. W.; Tsai, G. Glycine transporter 1 inhibitor, $N$ methylglycine (sarcosine), added to clozapine for the treatment of schizophrenia. Biol. Psychiatry, 2006, 60, 645-649.

[103] Lane, H.Y.; Chang, Y. C.; Liu, Y. C.; Chiu, C. C.; Tsai, G. E. Sarcosine or D-serine add-on treatment for acute exacerbation of schizophrenia: a randomized, double-blind, placebo-controlled study. Arch. Gen. Psychiatry, 2005, 62, 1196-1204.

[104] Lane, H.Y.; Liu, Y. C.; Huang, C. L.; Chang, Y. C.; Liau, C. H.; Perng, C. H.; Tsai, G. Sarcosine ( $N$-methylglycine) treatment for 
acute schizophrenia: a randomized, double-blind study. Biol. Psychiatry, 2008, 63, 9-12.

[105] Zhang, H. X.; Hyrc, K.; Thio, L. L. The glycine transport inhibitor sarcosine is an NMDA receptor co-agonist that differs from glycine. J. Physiol., 2009, 587, 3207-3220.
[106] Liem-Moolenaar, M.; Zoethout, R.; de Boer, P.; Schmidt, M.; de Kam, M.; Cohen, A.; Franson, K.; van Gerven, J. The effects of a glycine reuptake inhibitor R231857 on the central nervous system and on scopolamine-induced impairments in cognitive and psychomotor function in healthy subjects. J. Psychopharmacol., 2009, [Epub ahead of print].

(C) Kenji Hashimoto; Licensee Bentham Open.

This is an open access article licensed under the terms of the Creative Commons Attribution Non-Commercial License (http: //creativecommons.org/licenses/by$\mathrm{nc} / 3.0 /$ ) which permits unrestricted, non-commercial use, distribution and reproduction in any medium, provided the work is properly cited. 